\section{How to define 30-day mortality?}

\author{
To the Editor,
}

We have read with great interest the article titled "Evaluation of procedural and clinical outcomes of transcatheter aortic valve implantation: A single-center experience," which was written by Duran Karaduman et al. (1). The authors retrospectively published clinic results of 556 consecutive patients with symptomatic severe aortic stenosis (AS) who underwent transcatheter aortic valve implantation (TAVI) between July 2011 and December 2019. We thank the authors for their contribution of the present study, which is the largest single-center real-world experience of TAVI in Turkey. However, we have some concerns regarding the their findings. It is a confusing finding that the authors reported in-hospital mortality as $3.9 \%$ and 30 -day mortality as $2.2 \%$. What is meant by 30 -day mortality is not fully explained in the methodology section. According to the consensus document of the Valve Academic Research Consortium-2 (VARC-2), procedural mortality consists of all-cause mortality within 30 days or index procedure hospitalization if the postoperative stay is longer than 30 days (2). It is understood that the 21 patients who died in the in-hospital period were not included in the statistical analysis in the calculation of mortality at 1-month follow-up. This situation should be stated in the methodology section with its justifications, or all patients who died during the 1-month follow-up period should be included in the statistical analysis.

Ali Rıza Akyüz (D), Levent Korkmaz (D)

Department of Cardiology, University of Health Sciences, Trabzon Ahi Evren Cardiovascular and Thoracic Surgery Training and Research Hospital; Trabzon-Turkey

\section{References}

1. Duran Karaduman B, Ayhan H, Keleş T, Bozkurt E. Evaluation of procedural and clinical outcomes of transcatheter aortic valve implantation: A single-center experience. Anatol J Cardiol 2020; 23 : 288-96. [Crossref]

2. Généreux P, Head SJ, Van Mieghem NM, Kodali S, Kirtane AJ, Xu K, et al. Clinical outcomes after transcatheter aortic valve replacement using valve academic research consortium definitions: a weighted meta-analysis of 3,519 patients from 16 studies. J Am Coll Cardiol 2012; 59: 2317-26. [Crossref]

Address for Correspondence: Dr. Ali Rıza Akyüz,

Trabzon Ahi Evren Göğüs Kalp ve Damar Cerrahisi Eğitim ve Araştırma Hastanesi, Kardiyoloji Kliniği, 61000 Trabzon-Türkiye

Phone: +905065051619

E-mail: dralirizaakyuz@gmail.com

CCopyright 2021 by Turkish Society of Cardiology -

Available online at

www.anatoljcardiol.com

DOI:10.5152/AnatolJCardiol.2021.60026

\section{Author`s Reply}

To the Editor,

We thank the authors for their concern in our article (1) and for allowing us to provide additional details that might enhance the understanding of our results. In this letter, the authors discussed the definition of 30-day mortality in TAVI. As it is understood from the letter, the point where the authors are confused is that the 30-day mortality and in-hospital mortality were given separately in our article. The authors mentioned that we should add in-hospital mortality to 30-day mortality based on the procedural mortality definition stated in VARC-2 (2). However, in VARC2 , procedural mortality and immediate procedural mortality definitions were provided separately, and it was stated that the procedural mortality was defined by considering the surgical literature. As is known, the definitions used by the surgical literature were preferred because one arm of the study is the surgical method. Immediate procedural mortality definition is as follows: VARC-2 suggests the accumulation of direct procedural mortality to obtain intra-procedural cases that occur in immediate or following death $<72$ hours post-procedure (2). Procedural mortality definition is as follows: deaths from all causes within 30 days or during the index procedure hospitalization, if the postoperative stay is longer than 30 days.

Furthermore, in-hospital mortality and 30-day mortality rates were given separately in large registry or retrospective studies, such as our study $(3,4)$. The definition of in-hospital survival in the German Aortic Valve Registry, which the aim of this study was to analyze in-hospital, short-term, and 1-year outcome in patients undergoing isolated TAVI or surgical aortic valve replacement (SAVR), was as follows: it was documented upon discharge or death by the index hospital (3). Moreover, in the study comparing TAVI and SAVR in kidney transplant recipients, patients who died within index hospitalization were excluded while calculating the 30-day mortality (5). As stated by the authors, the determination that the 21 patients who died during the hospital period were not included in the statistical analysis in the calculation of mortality in 1-month follow-up is misunderstood, and it is clear that these patients died within 30 days after discharge from the hospital. From our article, the procedural mortality rate according to VARC-2 can be obtained over inhospital and 30-day mortality rates. With this letter pointed out by the authors, the evaluation of deaths within 30 days as procedural mortality in TAVI, which is not a surgical procedure, should be discussed by the literature again.

\footnotetext{
Bilge Duran Karaduman (D), Hüseyin Ayhan (D), Telat Keleş ${ }^{1}$ (D), Engin Bozkurt² (iD

Department of Cardiology, Faculty of Medicine, Atılım University, Medicana International Ankara Hospital; Ankara-Turkey 1Department of Cardiology, Faculty of Medicine, Ankara Yıldırım Beyazıt University, Ankara City Hospital; Ankara-Turkey 2Department of Cardiology, Medicana International Ankara Hospital; Ankara-Turkey
} 


\section{References}

1. Duran Karaduman B, Ayhan H, Keleş T, Bozkurt E. Evaluation of procedural and clinical outcomes of transcatheter aortic valve implantation: A single-center experience. Anatol J Cardiol 2020; 23: 288-96. [Crossref]

2. Kappetein AP, Head SJ, Généreux P, Piazza N, van Mieghem NM, Blackstone $\mathrm{EH}$, et al. Updated standardized endpoint definitions for transcatheter aortic valve implantation: the Valve Academic Research Consortium-2 consensus document. Eur Heart J 2012; 33: 2403-18. [Crossref]

3. Werner N, Zahn R, Beckmann A, Bauer T, Bleiziffer S, Hamm CW, et al.; GARY Executive Board. Patients at Intermediate Surgical Risk Undergoing Isolated Interventional or Surgical Aortic Valve Implantation for Severe Symptomatic Aortic Valve Stenosis. Circulation 2018; 138: 2611-23. [Crossref]
4. Vendrik J, van Kesteren F, van Mourik MS, Piek JJ, Tijssen JG, Henriques JPS, et al. Procedural Outcome and Midterm Survival of Lower Risk Transfemoral Transcatheter Aortic Valve Implantation Patients Treated With the SAPIEN XT or SAPIEN 3 Device. Am J Cardiol 2018; 121: 856-61. [Crossref]

5. Abdelfattah OM, Saad AM, Abushouk A, Hassanein M, Isogai T, Gad MM, et al. Short-Term Outcomes of Transcatheter Aortic Valve Implantation Versus Surgical Aortic Valve Replacement in Kidney Transplant Recipients (from the US Nationwide Representative Study). Am J Cardiol 2021; 144: 83-90. [Crossref]

Address for Correspondence: Dr. Engin Bozkurt,

Medicana International Ankara Hastanesi, Kardiyoloji Kliniği, Ankara-Türkiye Phone: +905306945353

E-mail: drebozkurt@yahoo.com.tr

(C) Copyright 2021 by Turkish Society of Cardiology - Available online at www.anatoljcardiol.com 